\title{
Analisis Finansial Pengembangan Industri Sagu Melalui UMKM di Distrik Tomu Kabupaten Teluk Bintuni
}

\author{
Ardha Puspita Sari \\ Dosen Fakultas Pertanian, Universitas Papua \\ Permalink/DOI: http://dx.doi.org/10.32830/jfres.v1i1.1013.g762 \\ Received: Mey 2018; Accepted: July 2018; Published: September 2018
}

\begin{abstract}
Abstrak
Perekonomian Distrik Tomu pada umumnya masih menganut sistem tradisional. Upaya pengembangan ekonomi di Distrik Tomu dari sistem tradisional ke modern dapat dimulai dengan mengembangkan industri rumah tangga. Salah satu sumber daya yang dapat dimanfaatkan untuk mengembangkan industri rumah tangga di Distrik Tomu adalah sagu. Distrik Tomu memiliki kawasan hutan sagu cukup luas yaitu 51,804 ha. Tujuan penelitian ini adalah untuk mengetahui peluang pasar dan kelayakan finansial pengembangan industri sagu melalui UMKM di Distrik Tomu. Berdasarkan hasil analisis, diproyeksi produksi sagu basah industri rumah tangga di Distrik Tomu adalah $320 \mathrm{Kg} /$ batang. Dalam sehari industri ini diharapkan bisa mengolah 1 batang sagu. Dalam sebulan total produksi industri sagu rumah tangga dapat mencapai 20 batang sagu. Dengan rata-rata harga jual di Kabupaten Bintuni adalah Rp 15.000/Kg sagu basah, maka rata-rata pendapatan yang diperoleh adalah Rp 39.474.417 per sekali proses produksi. Hasil proyeksi perhitungan B/C rasio, NPV dan IRR menunjukkan bahwa industri pengolahan sagu di Distrik Tomu dikatakan layak secara finansial. Diharapkan pengembangan industri sagu skala rumah tangga di Distrik Tomu dapat berjalan sesuai dengan proyeksi harga yang ada.
\end{abstract}

Kata kunci: sagu, peluang pasar, kelayakan usaha

\begin{abstract}
Tomu District's economy in general still adheres to the traditional system. Economic development efforts in Tomu District from traditional to modern system can be started by developing a home industri. One resource that can be utilized to develop the home industri in Tomu District is sago. Sago forest area in this district is wide enough, that is 51,804 ha. The purpose of this research is to figure out the market opportunity and financial feasibility of the sago industri development through UMKM in Tomu District. Based on the analysis, the projection of wet sago production of home industri in Tomu District is $320 \mathrm{Kg} /$ trunk. The industri is expected to process 1 trunk of sago in a full day operation. In average, the industry can process approximately 20 trunks of sago per month. With the average selling price in Bintuni Regency is Rp. $15.000 / \mathrm{Kg}$ wet sago, then the average income earned in one production process is projected to reach $R p$ 39.474.417. The projection results of $B / C$ ratio, NPV and IRR indicated that sago processing industry in Tomu District was financially feasible. It is then expected that the development of sago home industry in Tomu District can be operated in accordance with the projected price.
\end{abstract}

Keywords: sago, market opportunity, business feasibility

How to Cite: Sari, A.P. (2018). Analisis Finansial Pengembangan Industri Sagu Melalui UMKM di Distrik Tomu Kabupaten Teluk Bintuni. JFRES: Journal of Fiscal and Regional Economy Studies, 1 (1), 10-16. doi: http://dx.doi.org/10.32830/jfres.v1i1.1013.g762 


\section{PENDAHULUAN}

Distrik Tomu merupakan distrik pemekaran dari Distrik Aranday di Kabupaten Teluk Bintuni, yang daerahnya adalah sebagian dataran rendah dengan ketinggian rata-rata 4,25 meter diatas permukaan laut, dan luas wilayah mencapai 572 $\mathrm{Km}^{2}$. Topografi Distrik Tomu berupa daerah aliran sungai, yang hampir semua wilayahnya berbatasan langsung dengan Sungai Sebyar (Distrik Tomu Dalam Angka, 2015). Karena letak Distrik Tomu yang berada di daerah pesisir dan pinggiran sungai sehingga masyarakat Tomu yang ingin ke distrik lain ataupun ke Kabupaten Teluk Bintuni harus menggunakan fasilitas perahu motor karena belum ada jalan darat yang mencapai Distrik Tomu. Keadaan seperti ini sangat mempengaruhi sistem perekonomian di Distrik Tomu. Untuk hal yang paling mendasar seperti memenuhi kebutuhan pokok keluarga, masyarakat harus mengeluarkan biaya yang relatif lebih tinggi untuk membeli di ibukota Kabupaten Teluk Bintuni. Pada umumnya, perekonomian Distrik Tomu masih menganut sistem perekonomian tradisional, dimana perekonomiannya masih berupa: 1) Eksplorasi hasil alam (meramu), misalnya sagu, berburu dan menangkap hasil laut seperti udang dan ikan; 2) Pertanian, masih pertanian subsisten; 3) Perdagangan antar kampung yang sangat mengandalkan jalur laut.

Upaya pengembangan ekonomi di Distrik Tomu dari sistem tradisional ke modern dapat dimulai dengan mengembangkan industri rumah tangga. Industri rumah tangga adalah salah satu kegiatan yang banyak dilakukan oleh masyarakat di pedesaan untuk meningkatkan pendapatan keluarga. Industri kecil dan rumah tangga sangatlah penting karena dapat menyerap kelebihan tenaga kerja dan memacu pertumbuhan ekonomi pedesaan. Industri kecil mempunyai ciri-ciri sebagai berikut 1) menggunakan teknologi sederhana atau madia; 2) padat karya; 3) relatif menyerap banyak tenaga kerja; 4) pada umumnya tumbuh secara berkelompok menurut jenisnya atau membentuk sentra dan 5) berakar dari bakat keterampilan atau bakat seni (Suratiyah dkk., 1994).

Salah satu sumber daya yang dapat dimanfaatkan untuk mengembangkan industri rumah tangga di Distrik Tomu adalah sagu. Sagu merupakan komoditas potensial sebagai bahan substitusi dan bahan baku untuk industri. Sebagai salah satu sumber karbohidrat, potensinya belum dimanfaatkan secara maksimal di Distrik Tomu. Sagu memiliki peranan yang sangat penting dalam sistem sosial, ekonomi dan budaya masyarakat adat di Papua terutama yang bermukim pada agroekosistem dataran rendah, rawa, sungai, pantai dan kepulauan termasuk Distrik Tomu Kabupaten Teluk Bintuni. Terdapat dua peranan utama sagu di kalangan masayarakat Bintuni, yaitu 1) sebagai makanan pokok, 2) sumber pendapatan dimana sagu dijual untuk memenuhi kebutuhan rumah tangga.

Distrik Tomu merupakan salah satu distrik yang memiliki kawasan hutan sagu cukup luas. Total luasan hutan sagu di distrik Tomu adalah 51,804 ha. Hutan sagu pada distrik Tomu merupakan daerah rawa yang terdiri dari hutan rawa primer seluas 40,460 ha, hutan rawa sekunder seluas 10,624 ha, dan belukar rawa seluas 720 ha. Sekitar 60 \% dari hutan sagu di Distrik Tomu merupakan Hutan Produksi Tetap (Tim Unipa, 2016).

Secara tradisonal sagu di Distrik Tomu masih rendah nilai ekonomisnya. Jumlahnya yang melimpah dan kualitas pengolahan yang rendah menyebabkan nilai ekonominya rendah pula. Dalam pengolahannya dihasilkan sagu basah dengan kualitas rendah dan dijual dengan harga Rp 15.000 /Kg. Dengan demikian dalam pengembangan teknologi menjadikan sagu sebagai bahan baku industri mempunyai potensi ekonomi yang penting.

Dari uraian diatas, maka pengembangan industri sagu di level usaha kecil dan menengah menjadi sangat penting untuk diterapkan. Penelitian ini bertujuan untuk: 1) mengetahui peluang pasar pengembangan industri sagu melalui UMKM di Distrik Tomu Kabupaten Teluk Bintuni; dan 2) menganalisis kelayakan finansial pengembangan industri sagu melalui UMKM di Distrik Tomu Kabupaten Teluk Bintuni.

\section{METODE PENELITIAN}

Kegiatan pengumpulan dan analisis data meliputi pengumpulan data sekunder, studi 
kepustakaan, dan pengamatan langsung (observasi) di lapangan. Data-data yang terkumpul diekstraksi sesuai dengan kebutuhan penelitian, sebelum diolah dengan metode tabulasi dan diperoleh informasi yang relevan guna menjawab tujuan penelitian ini. Setelah data terkumpul selanjutnya dilakukan analisis statistik deskriptif dan dilanjutkan dengan analisis peluang pasar dan studi kelayakan finansial pengembangan industri sagu. Analisis kelayakan finansial yang digunakan antara lain:

\section{a. Net Present Value (NPV)}

Analisis NPV dilakukan dengan menggunakan rumus sebagai berikut:

$$
\begin{aligned}
N P V=\frac{C F_{0_{1}}}{(1+r)^{1}}+ & \frac{C F_{0_{2}}}{(1+r)^{2}}+\frac{C F_{0_{3}}}{(1+r)^{3}} \\
& +\cdots \frac{C F_{0_{10}}+T C F}{(1+r)^{10}}-I_{0}
\end{aligned}
$$

NPV : Net Present Value

Cfo : Cash Flow Operational dari tahun ke 1 sampai tahun ke 5

n : 5 tahun.

Io : Jumlah investasi dalam proyek

$\mathrm{r} \quad$ : Tingkat bunga yang relevan (cost of capital)

TCF : Terminal Cash Flow

\section{b. Internal Rate of Return (IRR)}

Perhitungan IRR dilakukan dengan formula sebagai berikut:

$A_{0}=\frac{A_{1}}{(1+r)^{1}}+\frac{A_{2}}{(1+r)^{2}}+\frac{A_{3}}{(1+r)^{3}}+\cdots \frac{A_{10}}{(1+r)^{10}}$

Ao : Jumlah aliran kas awal

A 1 - A 10 : Jumlah aliran kas masuk

r $\quad$ : Internal Rate of Return

Jika nilai $r$ lebih tinggi dari cost of capital (biaya modal) maka rencana pengembangan investasi dapat diterima, sebaliknya jika nilai r lebih rendah maka investasi dikatakan tidak layak.

\section{c. Net Benefit Cost Ratio}

Teknik analisis Net B-C Ratio digunakan untuk membandingkan antara keuntungan bersih yang telah di-discount positif dengan net benefit yang telah di-discount negatif. Jika nilai Net B/C lebih besar dari 1 maka investasi tersebut layak untuk dikerjakan sebaliknya jika Net B/C kurang dari 1 berarti investasi tersebut tidak layak untuk diteruskan.

\section{HASIL DAN PEMBAHASAN}

\section{Potensi pengembangan dan peluang pasar sagu}

Sagu merupakan komoditas andalan yang dapat digunakan sebagai sumber karbohidrat potensial. Sagu dimanfaatkan sebagai bahan pangan alternatif dalam bentuk pangan pokok seperti papeda dan sebagai pangan pendamping dalam bentuk sagu lempeng, sinali, bagea dan lain-lain. Selain itu, sagu digunakan sebagai tepung komplosit untuk substitusi tepung terigu. Pengembangan dan pemanfaatan sagu sangat strategis untuk menunjang dan menjamin ketersediaan pangan. Apalagi sagu terkenal sebagai tanaman yang tahan terhadap perubahan iklim, kekeringan, kebanjiran serta hama dan penyakit.

Pati sagu dapat dikelola menjadi makanan tradisional sagu, tepung sagu, dan aneka makanan seperti mie dan beragam jenis kue. Pati sagu mempunyai potensi dan prospek yang baik sebagai bahan baku industri seperti substrat fermentasi asetonbutanol-etanol (Gumbira et al, 1996), bahan baku pembuatan plastik degradable, industri gula cair (Sarungallo dan Murtiningrum, 2005) dan penyedap makanan (Bujang dan Ahmad, 2000) serta digunakan untuk sumber energi baru berupa bioetanol (Haska, 1996). Sagu sangat potensial dalam pengembangannya karena memiliki nilai ekonomis yang tinggi serta dimanfaatkan secara optimal dalam menerobos pangsa pasar lokal dan Internasional.

Berdasarkan laporan yang bersumber dari BAPPENAS tahun 2010 tentang luas areal dan produktivitas per pohon dari daerah-daerah produsen sagu serta hasil percobaan di laboratorium, diperkirakan produksi sagu mencapai 40 sampai 60 batang/ha/tahun dengan jumlah empulur 1 ton/batang serta kandungan aci sagu $18,5 \%$ sehingga dapat diperoleh hasil per hektar per tahun adalah 7 sampai 11 ton sagu kering. Secara teoritis, dari satu batang pohon sagu dapat dihasilkan 100 sampai $300 \mathrm{Kg}$ aci sagu 
kering. Rendemen total untuk pengolahan yang ideal adalah 15\%. Sementara itu, harga sagu basah di Papua Barat saat ini antara Rp10.000 sampai Rp 15.000 per $\mathrm{Kg}$, dengan demikian peluang bisnis sagu di Indonesia masih terbuka lebar, walaupun masih banyak kendala yang harus dihadapi.

Berdasarkan hasil penelitian Tarigan dan Ariningsih (2007), pengembangan industri rumah tangga sagu mempunyai peluang yang cukup besar untuk dikembangkan, dilihat dari segi geografis, ketersediaan bahan baku, teknologi, maupun kebijakan pemerintah. Namun kendala terbesar terletak pada budaya bertani petani sagu dan sistem pemilikan lahan yang dikuasai penduduk lokal sementara kegiatan industri dikuasai oleh pendatang.

Langkah pertama yang perlu dilakukan dalam rangka mengembangkan industri sagu adalah memutuskan dan menyerahkan pengembangan dan pembinaan komoditas sagu pada salah satu dinas teknis. Hal ini akan menuntun pemerintah melalui dinas terkait untuk lebih serius melakukan langkah operasional dalam pengembangan baik dari sisi peningkatan produksi agar bahan baku industri tersedia secara kontinu (Disperta/ Perkebunan), pengolahan dan pemasaran (Disperindag), teknologi (BPTP), maupun kelembagaan (KIPP).

Pengembangan industri rumah tangga sagu sebaiknya diprioritaskan untuk mendorong perkembangan industri kecil dan menengah di pedesaan. Karena subsistem pengolahan merupakan kelanjutan dari subsistem produksi maka bisa berperan sebagai bagian dari pendekatan permintaan. Teknologi yang kurang diadopsi memerlukan rekayasa ulang untuk menciptakan teknologi yang prosedur kerjanya lebih mudah dan murah. Kapasitas olah perlu disesuaikan dengan kemampuan ketersediaan bahan baku namun tetap dengan pertimbangan ekonomis.

Agar kegiatan industri rumah tangga sagu di Distrik Tomu bisa memberi peningkatan nilai tambah yang berkontribusi langsung pada peningkatan pendapatan masyarakat maka perlu membangun pola kemitraan yang adil antara petani produsen sagu, pelaku industri berbahan baku sagu dan pelaku pasar yang dapat memenuhi permintaan pasar lokal maupun ekspor. Pada tahap awal, pembentukan kerjasama ini perlu difasilitasi oleh pemerintah terutama dalam pembangunan infrastruktur, akses terhadap permodalan, pembinaan kewirausahaan dan promosi pasar.

\section{Analisis finansial}

Industri pengolahan sagu merupakan salah satu jenis industri dengan memanfaatkan tanaman sagu sebagai bahan baku utamanya, dimana sagu tersebut akan diolah sesuai dengan kebutuhan untuk dijual secara komersial. Dalam hal ini sagu tersebut diolah menjadi tepung sagu. Industri pengolahan yang ada di Distrik Tomu tergolong pengolahan yang bersifat semi mekanis dengan kapasitas 1 batang sagu per hari atau sekitar 100-320 Kg per hari serta bahan baku diperoleh dari daerah sekitar industri pembuatannya di Distrik Tomu.

Dalam proses produksi industri pengolahan sagu batang tidak lepas dari biaya produksi. Biaya produksi yang dikeluarkan oleh pengusaha terbagi atas biaya tetap antara lain biaya penyusutan dari gedung dan peralatan yang digunakan, biaya pajak serta biaya listrik. Sedangkan biaya variabel terdiri dari biaya bahan baku, biaya tenaga kerja, biaya bahan bakar, biaya pengemasan serta biaya transportasi.

Dalam industri pengolahan sagu ini yang menjadi hal utama adalah produksi sagu basah yang dihasilkan dari ekstraksi batang sagu. Untuk menghasilkan produksi yang tinggi dan berkualitas diperlukan suatu penanganan yang baik dari semua aspek oleh produsen sehingga dapat meningkatkan nilai tambah dari hasil yang diproses, yaitu dari bahan baku batang sagu diolah menjadi sagu basah yang kemudian dapat dijadikan bahan baku untuk pembuatan produk turunan lainnya. Dari kegiatan ini diharapkan dapat memberi peningkatan nilai tambah yang berkontribusi langsung pada peningkatan pendapatan pengusaha.

Berikut adalah asumsi-asumsi yang dipergunakan untuk analisis kelayakan pengembangan agroindustri sagu: 
1. Umur proyek diasumsikan berjalan selama sepuluh tahun.

2. Harga untuk seluruh output dan input yang digunakan dalam analisis adalah harga konstan.

3. Biaya investasi dikeluarkan dalam satu tahun yaitu tahun ke-1.

4. Produksi dimulai sejak tahun pertama, dengan jumlah produksi yang sama.

5. Tingkat suku bunga yang berlaku $10 \%$ per tahun (berdasarkan rata-rata suku bunga yang berlaku tahun 2016).

6. Skala usaha industri sagu dalam studi ini adalah skala UKM.

\section{Arus pengeluaran}

Arus pengeluaran yang dimaksud adalah biaya investasi dan biaya Operasioanl. Biaya investasi merupakan seluruh biaya yang dikeluarkan dari mulai usaha tersebut dilakukan sampai usaha tersebut mulai berjalan. Proyeksi biaya investasi indusri pengolahan sagu basah di Distrik Tomu disajikan pada Tabel 1.

Total biaya investasi adalah Rp 119.070.000, dengan biaya terbesar yaitu pada mesin ekstrak yaitu Rp 27.000.000, sedangkan biaya terkecil yaitu pada pengeluaran jarum jahit karung sebesar Rp 50.000. Berdasarkan daftar biaya investasi, maka dapat dihitung nilai penyusutan alat per tahun, yakni sebesar Rp 9.907.000. Perhitungan ini menggunakan asumsi bahwa umur ekonomis dari setiap alat adalah 10 tahun atau Rp 825.583 per bulan.

Biaya operasional merupakan keseluruhan biaya yang dikeluarkan selama proses produksi berlangsung. Biaya operasional industri pengolahan sagu terdiri dari biaya bahan baku, upah tenaga kerja, biaya pengemasan, biaya bahan bakar dan lain-lain. Biaya bahan baku berupa pembelian batang sagu dari masyarakat sekitar, dengan proyeksi harga Rp 2.000.000. Diasumsikan bahwa, 1 unit mesin dapat menghabiskan 1 batang sagu dalam 1 hari, sehingga paling banyak dalam 1 bulan produksi industri ini bisa mengolah 16-20 batang sagu.

Dalam analisis juga diproyeksikan bahwa untuk menjalankan 1 mesin pemeras sagu dan mesin ekstrak membutuhkan sedikitnya 3 orang tenaga kerja, dengan tingkat upah sebesar Rp 1.500.000 per orang. Total biaya operasional dalam menjalankan industri pengolahan sagu adalah Rp 36.500.000 (Tabel 2). Jika ditotalkan biaya operasional dan penyusutan peralatan, maka total biaya per bulan industri pengolahan sagu dapat mencapai Rp 37.325.583.

Tabel 1. Biaya investasi industri pengolahan sagu di Distrik Tomu

\begin{tabular}{clccrr}
\hline No & \multicolumn{1}{c}{ Uraian Biaya } & Jumlah & Satuan & Harga (Rp.) & Biaya (Rp.) \\
\hline 1 & Mesin parut & 1 & Unit & 8.000 .000 & 8.000 .000 \\
2 & Mesin ekstrak & 1 & Unit & 27.000 .000 & 27.000 .000 \\
3 & Gedung & 1 & Unit & 25.000 .000 & 25.000 .000 \\
4 & Bak pengendapan & 1 & Unit & 20.000 .000 & 20.000 .000 \\
5 & Ayakan & 1 & Unit & 12.000 .000 & 12.000 .000 \\
6 & Parutan & 1 & Unit & 120.000 & 120.000 \\
7 & Mesin pompa air & 1 & Unit & 1.000 .000 & 1.000 .000 \\
8 & Kain ayak & 4 & Meter & 50.000 & 200.000 \\
9 & Gerobak dorong & 4 & Unit & 500.000 & 2.000 .000 \\
10 & Jeregen & 3 & Unit & 100.000 & 300.000 \\
11 & Selang air & 40 & Meter & 10.000 & 400.000 \\
12 & Gergaji mesin & 1 & Unit & 3.000 .000 & 3.000 .000 \\
13 & Jarum karung & 10 & Unit & 5.000 & 50.000 \\
\hline \multicolumn{2}{c}{ Jumlah } & & & & $\mathbf{9 9 . 0 7 0 . 0 0 0}$
\end{tabular}

Sumber: Data primer (diolah), 2018 
Tabel 2. Biaya operasional per bulan industri pengolahan sagu di Distrik Tomu

\begin{tabular}{clccrr}
\hline No & \multicolumn{1}{c}{ Uraian Biaya } & Jumlah & Satuan & Harga (Rp.) & Biaya (Rp.) \\
\hline 1 & Pembelian batang sagu & 20 & Batang & 1.500 .000 & 30.000 .000 \\
2 & Tenaga kerja & 3 & Orang & 1.500 .000 & 4.500 .000 \\
3 & Bahan bakar & 100 & Liter & 10.000 & 1.000 .000 \\
4 & Biaya pengemasan & 1 & Paket & 1.000 .000 & 1.000 .000 \\
\hline & Jumlah & & & & $\mathbf{3 6 . 5 0 0 . 0 0 0}$ \\
\hline
\end{tabular}

Sumber: Data primer (diolah), 2018

\section{Arus penerimaan dan analisis kelayakan}

Besar kecilnya biaya produski dan nilai yang diperoleh dari produski sagu basah akan mencerminkan besar kecilnya pendapatan yang diterima oleh industri pengolahan sagu basah. Proyeksi besarnya produksi sagu basah industri rumah tangga di Distrik Tomu adalah 320 $\mathrm{Kg} /$ batang. Dalam sehari industri ini diharapkan bisa mengolah 1 batang sagu, sedangkan diperkirakan dalam sebulan total produksi yang dihasilkan bisa mencapai maksimum 20 batang sagu. Dengan harga jual di Kabupaten Bintuni Rp 15.000 per Kg sagu basah, maka pendapatan yang diperoleh adalah $\mathrm{Rp} 39.474 .417$ per sekali produksi.

Hasil perhitungan kelayakan finansial pengolahan sagu di Distrik Tomu meliputi perhitungan NPV, IRR, dan B/C ratio, seperti disajikan pada Tabel 3.

Tabel 3. Hasil analisis kelayakan finansial industri pengolahan sagu di Distrik Tomu

\begin{tabular}{ccr}
\hline No & Uraian & \multicolumn{1}{c}{ Hasil } \\
\hline 1 & Penerimaan & Rp. 76.800 .000 \\
2 & Pendapatan & Rp. 39.474 .417 \\
3 & B/C & 1,057569987 \\
4 & NPV & Rp. 29.457 .025 \\
4 & IRR & $44,80 \%$ \\
\hline Sumber: & Data primer (diolah) 2018
\end{tabular}

Dari data pada Tabel 3 terlihat bahwa berdasarkan perhitungan proyeksi rasio $\mathrm{B} / \mathrm{C}$, NPV dan IRR, pengembangan industri pengolahan sagu di Distrik Tomu dikatakan layak untuk dijalankan. Rasio B/C lebih besar dari 1 menunjukkan bahwa nilai benefit yang diperoleh akan lebih tinggi dari biaya yang dikeluarkan dalam investasi pengembangan industri sagu di level UMKM. Nilai IRR sebesar
44,80\% menunjukkan pengembalian nilai investasi lebih besar dari tingkat suku bunga yang relatif umum dipakai, yakni 10\%.

Dengan uji kelayakan finansial seperti ini, diharapkan pengembangan sagu di Distrik Tomu dapat berjalan sesuai dengan proyeksi harga yang ada. Dalam menjalankan produksi sagu di Distrik Tomu akan menghadapi beberapa kendala. Misalnya dalam persediaan bahan baku dan pemasaran. Dalam penyediaan bahan baku batang sagu, masyarakat dengan mudah memperolehnya dari wilayah sekitar tentu saja dengan mempertimbangkan hak ulayat kepemilikan hutan sagu. Selain itu, penebangan terus menerus hutan sagu mengakibatkan ketersediaan bahab baku sagu akan menjadi berkurang. Untuk itu perlu diadakannya budidaya sagu agar ketersediaan akan bahan baku tetap terjaga.

Masalah lain adalah pemasaran. Pemasaran menjadi ujung tombak keberlangsungan produksi pengolahan sagu di Distrik Tomu. Sulitnya akses keluar masuk ke Distrik Tomu menjadi kendala utama proses pemasaran sagu di Distrik Tomu. Hal ini perlu adanya perhatian dari pemerintah daerah dalam melancarkan akses keluar masuk Distrik Tomu, misalnya dengan membuat transportasi umum regional dengan harga terjangkau.

Jika industri rumah tangga pengolahan sagu telah berjalan dengan baik, maka diharapkan perekonomian modern di Distrik Tomu juga akan berkembang dengan baik. Pendapatan dan kesejahteraan masyarakat distrik akan meningkat. Peningkatan perekonomian masyarakat akan ditandai dengan ketersediaan barang-barang kebutuhan pokok rumah tangga yang selalu ada, peningkatan daya beli masyarakat, serta peningkatan pendapatan per kapita di Distrik Tomu. 


\section{KESIMPULAN}

Pengembangan industri rumah tangga sagu mempunyai peluang pasar yang cukup besar untuk dikembangkan di Distrik Tomu, dilihat dari segi geografis dan ketersediaan bahan baku. Langkah pertama yang perlu dilakukan dalam rangka mengembangkan industri sagu adalah memutuskan dan menyerahkan pengembangan dan pembinaan komoditas sagu pada salah satu dinas teknis agar bahan baku industri tersedia secara berkesinambungan. Berdasarkan perhitungan rasio B/C, NPV dan IRR maka industri pengolahan sagu di Distrik Tomu dikatakan layak secara finansial untuk dijalankan.

\section{DAFTAR PUSTAKA}

BPS, 2015. Distrik Tomu Dalam Angka. BPS Teluk Bintuni.

Bujang K and F.B. Ahmad. 2000. Production and Utilisation Sago in Malaysia. Proc The Internasional Sago Seminar. Sustainable Of Sago Plant As An Alternative Of Source of food and material for Agroindustry in The Third Milenium, Held in Bogor, Indonesia, March 2000.
Gumbara, S.E.D., D, Mangunwijaya, Darmako. A, Retnono dan Suprasono, 1996. Produksi Aseton-Butanol-Etanol dari Subtrat Hidrolisat Pati Sagu dan Anggok Tapioka Hasil Hidrolisi Enzimatis. Makalah Simposium Nasional Sagu III. Perkebunan Riau 27-28 Februari 1996.

Hazka, N. 1995. Alcohol Production From Sago Strach Granule by Simultanous Hidrolization and Fermentation Using $a$ Raw Strach Digesting Enzyme From Aspergillus Sp. No. 47 And Saccharumises Cereviseae. No. 32. ISHS Acta Horticultura Internasional Sago Symposium.

Herlina, M dan R. Sulistyono.1990. Respon Tanaman Kedelai (Glycine max L.Merr) pada Pemakaian Mulsa Jerami dan Tingkat Kandungan Air tanah yang Berbeda. Agrivita 13(1): 35-39

Sarungallo, Z. L and Murtiningrum. 2005. Production and Charrcterization of glucose syrup of Papua Sago Strach. Abstracts of the 8th Internasional Sago Symposium in Jayapura, Indonesia. Japan Sosiety For The Promotion Science. 